\title{
Fermentation process and physicochemical treatment applied to dairy industry: an approach for waste management (production and use) and new perspectives in the transformation of these residues in value-added products
}

\author{
Leandro Freire dos Santos ${ }^{1 *}$, Cibely Maria Gonçalves ${ }^{1}$, Hélio Hiroshi Suguimoto ${ }^{1}$ \\ ${ }^{1}$ Dairy Science and Technology, Center of Research and Post Graduation, University of \\ Northern Parana. \\ *corresponding author: leandrofreire@onda.com.br
}

\section{ABSTRACT}

Studies point out several initiatives to reduce the pollutant load from dairy industry, leading to enhanced sustainability, including reduced environmental impacts and cost savings. This review provides a summary of the recent strategies focused on physicochemical treatments and fermentation processes to produce value-added products from cheese whey, such as bioactive proteins, ribonucleotides, biodegradable plastics, biogas, hydrogen gas, organic acids, and ethanol. The environmental costs and production aspects of dairy waste will be also addressed. The polluting potential and the high environmental costs of the waste produced by the dairy industry may be mitigated by dairy waste management.

Keywords: biotransformation, whey, dairy industry, wastewater. 


\section{RESUMO}

Pesquisas apontam várias iniciativas para reduzir a carga poluidora de resíduos da indústria láctea, os quais podem levar a uma maior sustentabilidade, diminuição dos impactos ambientais, bem como redução dos custos de tratamento. Este revisão fornece um compilado de recentes estratégias, baseadas em tratamentos físicoquímicos e processos fermentativos, para a produção de compostos de valor agregado tais como proteínas bioativas, ribonucleotídeos, plásticos biodegradáveis, biogás, hidrogênio, ácidos orgânicos e etanol. Este estudo também examinará aspectos gerais dos processos fermentativos, bem como uma análise de custos ambientais e aspectos de produção dos resíduos lácteos. O potencial poluidor, bem como os altos custos ambientais de resíduos produzidos pela indústria láctea, pode ser reduzido pelo manejo destes resíduos lácteos.

Palavras-chave: Biotransformação, soro de queijo, indústria láctea, águas residuárias. 


\section{INTRODUCTION}

Global dairy industry consists of a variety of countries and has a pungent consumer market. In addition, the dairy supply chain is unique, once milk is a primer product that can be produced every day (365 days per year) without significant climate interferences (Douphrate et al., 2013). The final products of this productive chain also have great nutritional value as cheese and yoghurts, besides being a vehicle for adding bioactive compounds (Daniel, Huerta, Mendoza, \& Sosa, 2013; Sharafedtinov et al., 2013). However, the modern dairy productive chain produces huge amounts of waste due to inherent manufacturing processes and production scheduling (Krzeminska, Neczaj, \& Parkitna, 2013). These wastes are polluting, due to the high chemical oxygen demand for oxidative stabilization of organic matter. Furthermore, the organic content of waste is immense, which generates high environmental costs (Powell, Broughton, Pratt, \& Shilton, 2013).

Cheese whey stands out between wastes originating from dairy productive chain, with a worldwide production estimated at $10^{8}$ tons per year. A small amount of whey is used by industries to produce value-added products and therefore minimize environmental impacts. Organic acids, oligonucleotides, biodegradable plastics, biogas, hydrogen gas, and ethanol are among the products derived from whey (Fernandez, Carracedo, Martinez, Gomez, \& Moran, 2014; Hungaro, Calil, Ferreira, Chandel, \& da Silva, 2013; Koushki, Jafari, \& Azizi, 2012; Madureira et al., 2013; Powell et al., 2013; Sharma \& Luzinov, 2012). This review focused on the contribution of physicochemical treatments and fermentation processes on the management of cheese whey, and the strategies for the production of value added products. Other aspects will also be 
considered including the environmental costs, production and recovery of whey, and general aspects of the fermentation processes.

\section{ENVIRONMENTAL COSTS: ANALYSIS OF THEIR IMPACT ON CHEESE INDUSTRY}

The environmental costs of milk production chain, specifically cheese, are very large, as demonstrated in Table 1 (Wissmann, Hein, Follmann, \& Rachow, 2012). They reflect directly on the operational costs which are relevant economic, political, and social factors (Magalhaes, Rodrigues, \& Da Silveira, 2012). Thus, high operational costs mean a weak global economy and low growth.

Among the significant factors in the environmental costs, the cost of treatment

of whey ranks first, followed by of electricity costs (Table 1). Thus, the revenue obtained from the biotransformation of cheese whey into value-added products is extremely interesting, considering the environmental costs and money-saving in the final process. 
Table 1 - Factors that account for environmental costs in cheese production (Wissmann et al., 2012) ${ }^{*}$.

\begin{tabular}{llll}
\hline ---- Environmental costs*----- & $---2008 * *--$ & $---2009 * *---$ & $---2010 * *---$ \\
\hline Total production in liters & 6.648 .688 & 8.225 .825 & 9.589 .265 \\
Costs of whey treatment & $1,56 \%$ & $1,69 \%$ & $1,63 \%$ \\
Costs of other wastes treatment & $0,03 \%$ & $0,03 \%$ & $0,03 \%$ \\
Electric power consumption & $2,55 \%$ & $2,33 \%$ & $2,28 \%$ \\
Water consumption & $0,26 \%$ & $0,25 \%$ & $0,22 \%$ \\
Firewood consumption & $0,56 \%$ & $0,53 \%$ & $0,52 \%$ \\
Costs of insalubrity & $0,73 \%$ & $0,80 \%$ & $0,80 \%$ \\
Total environmental costs & $5,70 \%$ & $5,63 \%$ & $5,48 \%$ \\
Total values/ whey treatment*** & $\mathrm{RS} 80.781,56$ & $\mathrm{R} \$ 99.943,77$ & $\mathrm{R} \$ 116.509,57$ \\
\hline
\end{tabular}

* Compilation from a dairy farm in Paraná state / modified table.

** Environmental costs and their representation in the operational costs.

*** Costs of treatment of effluents using membrane ultrafiltration process.

\section{WHEY - PRODUCTION ASPECTS}

Cheese whey is produced in three main points of the cheese production chain: coagulation, cutting the curd, and molding and pressing (Figure 1). Whey represents 80 to $90 \%$ of the total volume of milk, and contains about $50 \%$ of the milk nutrients including lactose, vitamins, minerals, and soluble proteins (Micinski, Zwierzchowski, Kowalski, \& Szarek, 2013; Siqueira, Machado, \& Stamford, 2013). Thus, despite the high potential for the environmental contamination discussed in the previous section, cheese whey has nutritional importance and can be treated as a byproduct of the dairy production chain rather than waste (Micinski et al., 2013; Siqueira et al., 2013). Some aspects of the use and recovery of whey will be discussed in the next section. 


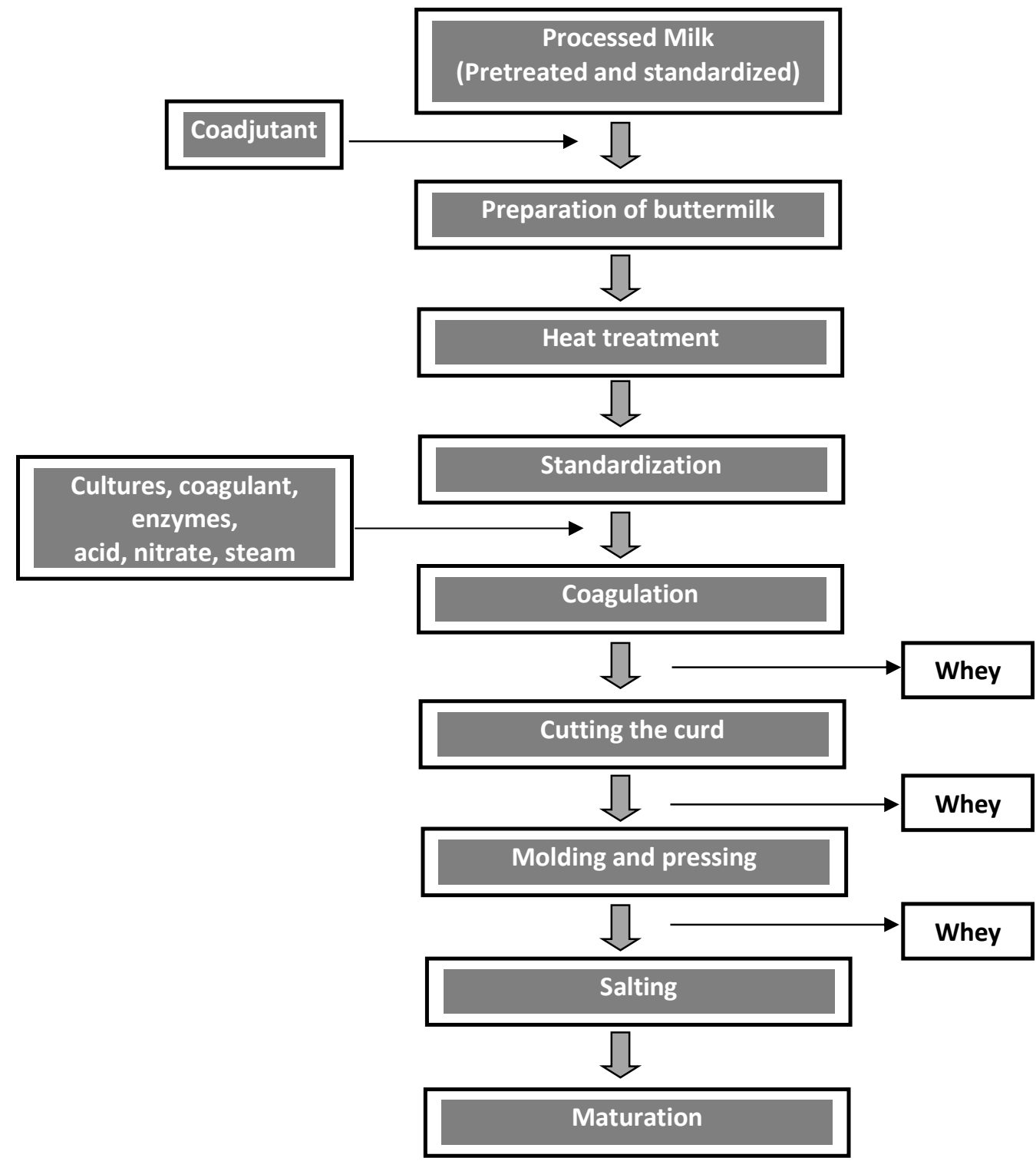

Figure 1-Manufacturing process of cheese and whey.

\section{USE AND RECOVERY OF CHEESE WHEY}

Cheese whey can be used in natura or submitted to various industrial processes for the preparation of derivatives (Figure 2) (Fornal, Jackson, Anderson, \& Greer, 2012; Pazo, Araujo, Rodriguez, Dieguez, \& Dominguez, 2013). Such approaches aim at 
minimizing the environmental impact by decreasing its volume dump. Among the uses in nature, we highlight its addition in feed, fruit juice, beverage manufacturing, and whey creams. Animal feed rich in succinate was obtained by using cheese whey. Succinate is a direct precursor responsible for the formation of up to $73 \%$ of propionate in rumen. Proprionate has been associated with a high performance of animal confinement (Samuelov, Datta, Jain, \& Zeikus, 1999). Industrial uses include the whey protein isolate that can be used as a gelation inducing agent (Zhang, Hsieh, \& Vardhanabhuti, 2014), or for extraction of lactose, which may be substrate for the synthesis of galacto-oligosaccharides. These agents have recognized prebiotic action, providing great intestinal flora benefits (Malinovska, Fernandes, Winkelhausen, \& Fonseca, 2012). 


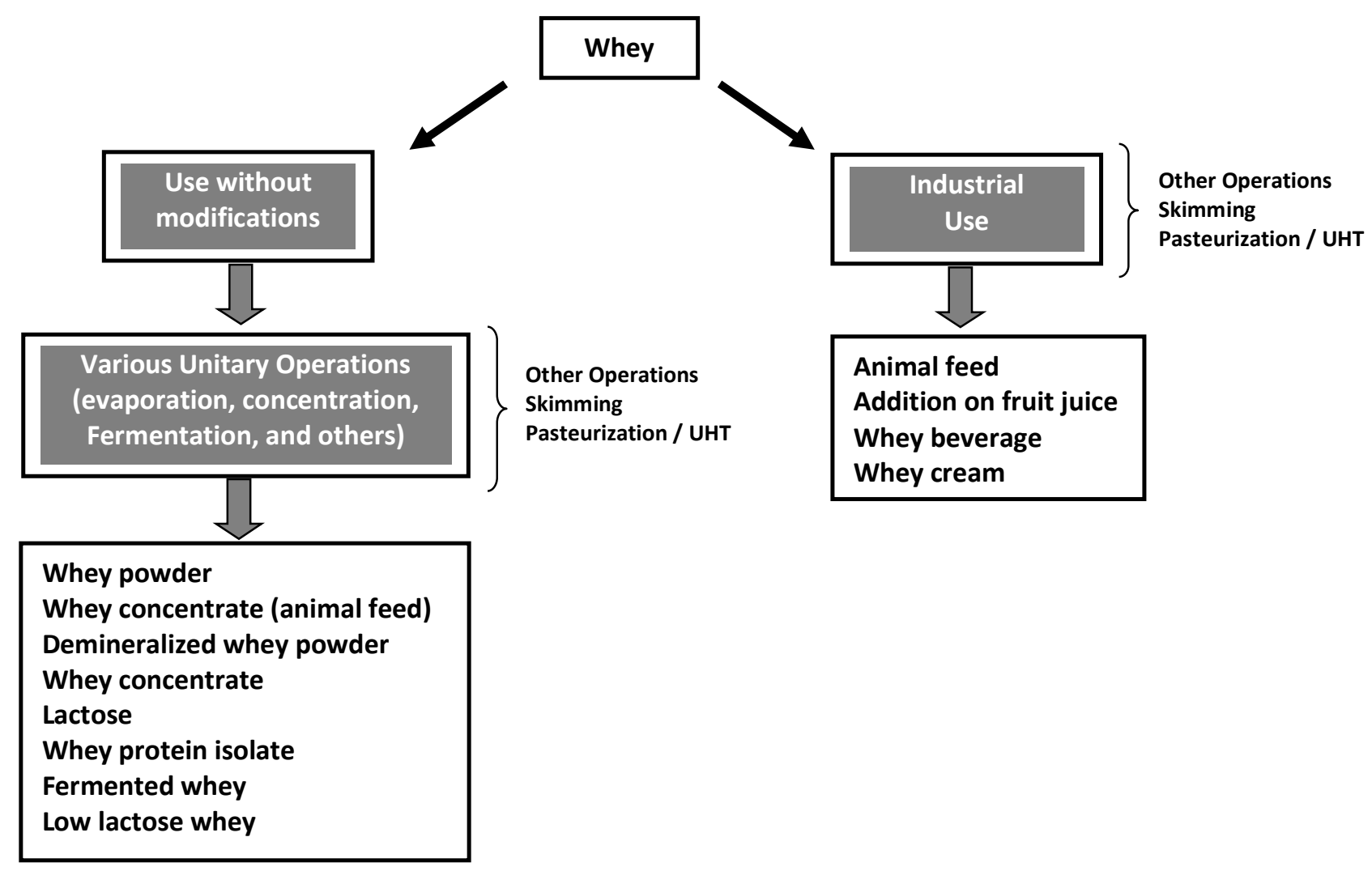

Figure $\mathbf{2}$ - Recovery process of cheese whey.

\section{FERMENTATION PROCESS}

Fermentation is an anaerobic process for the synthesis of energy (ATP) without the involvement of respiratory chain. Respiratory chain is a characteristic step of the cellular respiration process in which oxygen is the final electron acceptor (Sommer, Ghofrani, \& Schermuly, 2008). During fermentation, the electron acceptor is an organic compound (Jeon \& Choi, 2010). Thus, the fermentation process can be useful for obtaining energy in the absence of oxygen. In some cases, such as in the production of citric acid, fermentation occurs in the presence of oxygen, also called aerobic fermentation (Sekiyu, 1992). Thus, it appears that the fermentation is a process of generating energy, in which an incomplete oxidation of organic compounds occurs, such as glucose. 
Two basic types of fermentation can be used in the dairy industry: liquid or submerged fermentation and solid-state fermentation. Submerged fermentation is characterized by the use of a liquid medium, which can be added of soluble nutrients. Among the advantages of this type of process are the ease of control of $\mathrm{pH}$, temperature, and aeration, agitation, besides the possibility of automation given by the fluids dynamic (Dos Santos et al., 2013). For example, from dairy waste lipases can be produced for environmental control using submerged fermentation processes (Roveda, Hemkemeier, \& Colla, 2010).

The solid-state fermentation involves microbial growth on solid substrates with low water activities. Although there are difficulties in controlling and monitoring the parameters in solid-state fermentation, it requires the use of less complex equipment, low energy demand, and low operational costs (Holker \& Lenz, 2005). Cheese ripening is a solid fermentation and consists of a series of processes of a physical, chemical, and microbiological nature (Rademaker, Hoolwerf, Wagendorp, \& Giffel, 2006). Some variations of this technique also employ an inert gas to give a solid substrate to support microbial growth. In this case, it may be called solid-state fermentation, or even semi-solid state fermentation (Machado, Teixeira, \& Couto, 2013).

\section{PHYSICOCHEMICAL TREATMENTS AND FERMENTATION PROCESS APPLIED IN DAIRY WASTE MANAGEMENT (CHEESE INDUSTRY)}

The whey is an important substrate for the fermentation process, physicochemical treatment and thus obtains value-added products (Table 2). Some of the strategies for the use of this waste will be addressed in the following topic. 
Table 2 - Overview of all bioproducts obtained from dairy waste management addressed in this review.

\begin{tabular}{cc}
\hline --- Value - added products ---- & --- References --- \\
\hline Protein and their conjugates & (Carvalho et al., 2014) \\
Ribonucleotides & (Hungaro et al., 2013) \\
Biodegradable plastics & (Sharma, Hodges, \& Luzinov, 2008) \\
Hydrogen gas and biogas & (Powell, Broughton, Pratt, \& Shilton, \\
& 2013; Shilton et al., 2013) \\
Organic acids & (Madureira et al., 2013; Mullin \& \\
& Emmons, 1997). \\
Ethanol & (Koushki, Jafari, \& Azizi, 2012) \\
\hline
\end{tabular}

\subsection{Proteins and their conjugates}

Important bioactive proteins and conjugates can be isolated from cheese whey, with great appeal to the pharmaceutical industry. Lactoferrin is a glycoprotein, which belongs to the family of iron transporters, and is also considered a multifunctional protein. It presents an important role in uptake of iron by the intestinal mucosa of infants, once lactoferrin seems to be a source of iron for breastfed babies. Other properties also include antioxidant, immunomodulatory, anti-inflammatory, antimicrobial, antihypertensive, and anticancer activities (Musoles et al., 2014; Queiroz, Assis, \& Júnior, 2013; Yin, Wong, Xia, \& Ng, 2013). Due to their biological effects, the productive sector has made major investments for its extraction from cheese whey. Separation methods using composite macroporous cryogel columns of polyacrylamide loaded with $\mathrm{Cu}^{2+}$ can be used for isolation and purification of lactoferrin from whey, which provide higher yields and lower costs to industry 
(Carvalho et al., 2014). Other processes using reactive Yellow HE-4R in affinity chromatography systems are also used (Baieli, Urtasun, Miranda, Cascone, \& Wolman, 2014). After isolation and purification, lactoferrin may be encapsulated and dispersed in new food products or directly administered via inhalation (Balcao et al., 2013; Oguejiofor, Marshall, Price, \& Shur, 2013).

Interestingly, studies have shown biological effects such as anti-hypertensive action, not only from crude proteins, but also from whey protein isolates submitted to enzymatic hydrolysis (Silva et al., 2014).

Immunoglobulins $\mathrm{G}$ are glycoproteins with important actions in opsonization, activation of complement system, and in the antibody-dependent cell-mediated cytotoxicity mechanism (Jones, 1973)' and thus have extensive immunomodulatory action. Cheese whey can be considered as a potential source of immunoglobulin G. Among the techniques used for isolation and purification of immunoglobulins $G$, there are the ion exchange chromatographic techniques with Streamline Direct CST I (SDC) (Du, Lin, Zhang, \& Yao, 2014). The SDC is a new type of ion exchange technique with multimodal functional groups, which can capture proteins from raw materials with high ionic strength and high binding capacity (Li, Xiu, Mata, Grande, \& Rodrigues, 2006).

Beta-lactoglobulin (BLG) is a small globular protein found in cheese whey, with important immunomodulatory actions (Carrio, Fernandez, Riera, \& Suarez, 2014). However, its major applications in technological field include the use as dispersants for carbon nanotubes (Karchemsky et al., 2013). BLG has been considered a potential 
natural source of serine proteases, which are involved in the degradation and inactivation of incretins. Incretins are a class of substances produced by the pancreas and intestines capable of stimulating glucose metabolism (Silveira, Martinez-Maqueda, Recio, \& Ledesma, 2013). Microfiltration and ultrafiltration techniques are widely employed for BLG purification (Sierra, Tolkach, \& Kulozik, 2013).

Alpha-lactalbumin (LAC) is a major milk protein, also found in cheese whey, with important biological actions. Diets enriched with LAC possess anxiolytic and antidepressant activities (Vekovischeva et al., 2013). As BLG, LAC may be extracted by microfiltration and ultrafiltration techniques, preventing structural instability provided by extraction methods using heat or salts (Sierra et al., 2013). Another important issue in downstream processing of milk proteins is the selective separation of BLG and LAC. Some techniques for BLG isolation consist in enzymatic hydrolysis of LAC, under acidic conditions, with BLG in its native form (Cheison, Bor, Faraj, \& Kulozik, 2012). For selective separation of LAC, several techniques use chymotrypsin for enzymatic hydrolysis of BLG (Lisak, Sierra, Kulozik, Bozanic, \& Cheison, 2013).

\subsection{Ribonucleotides}

Ribonucleotides have shown promising applications in food and pharmaceutical industries. In food industry, ribonucleotides have been used as flavor enhancers and probiotics (Ventanas, Mustonen, Puolanne, \& Tuorila, 2010). In pharmaceutical field, ribonucleotides are used as immunomodulatory, antitumor and antiviral agents (Hungaro et al., 2013; Schaller, Buck, \& Rueda, 2007). Kluyveromyces marxianus, using cheese whey as the main substrate for fermentation process, can produce great 
amounts of ribonucleotides, being an important strategy to overcome the polluting effect of whey by reducing the biochemical oxygen demand. For the production of ribonucleotides (Figure 3), whey should be deproteinized with hydrochloric acid (32\%) to $\mathrm{pH} 4.3$, followed by sterilization, cooling and filtration. After addition of the inoculum and consequent fermentation, samples are collected for analysis of ribonucleotides. The ribonucleotides are released to the fermentation medium after the autolysis (water bath at $60^{\circ} \mathrm{C}, 80 \mathrm{rpm}$ for $24 \mathrm{~h}$ ), and then samples should be centrifuged. The supernatant reacts with an orcinol solution in boiling bath for $30 \mathrm{~min}$. After this period, samples are cooled and quantified spectrophotometrically at $660 \mathrm{~nm}$ (Hungaro et al., 2013). 


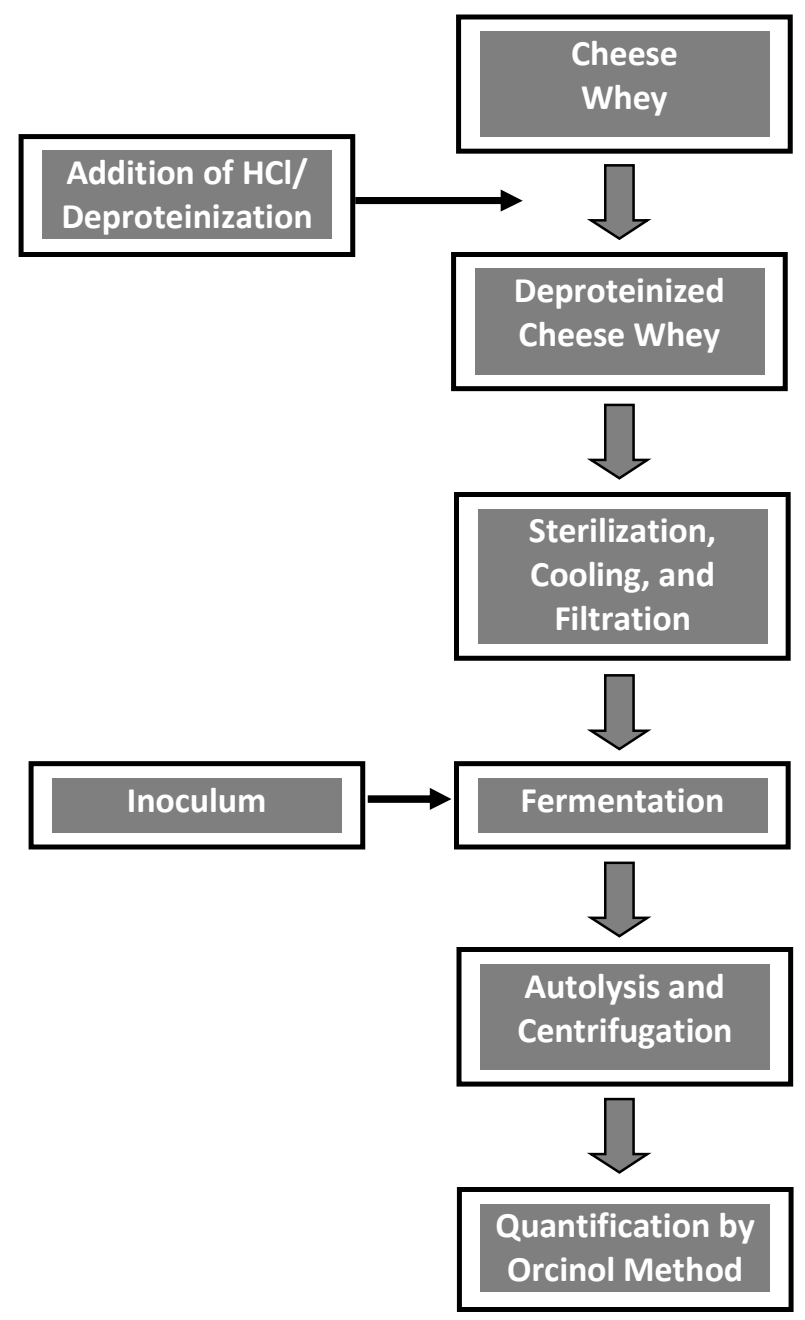

Figure 3 - Critical points to produce ribonucleotides from cheese whey.

\subsection{Biodegradable Plastics}

The development of new polymeric materials to replace petroleum-derived synthetic polymers has focused on the use of biopolymers such as proteins, starches, cellulose, and lipids, which may be obtained from by-products or co-products generated in agricultural sector. From these biomolecules, whey proteins stand out in the manufacture of fibers, plastics, and films with biodegradable characteristics (Sharma, Hodges, \& Luzinov, 2008). The so-called biodegradable plastics have similar 
physical and chemical properties to those of ordinary plastics, except for the degradation time, which is approximately 10 times smaller. Studies show an increase in global demand for bioplastics in the order of $15 \%$ by 2017 (Thinnes, 2013).

Studies have shown that plastics can successfully be produced through a mixture of whey protein and water by compression molding processes. The plastics present characteristics of amorphous hydrophilic polymer and good biodegradability and viscoelasticity (Sharma \& Luzinov, 2012). In addition to the use of whey protein isolate for the manufacture of bioplastics, cheese whey permeate can first be fermented to lactic acid - an important component of bioplastics (Fitzpatrick, Murphy, Mota, \& Pauli, 2003). Biodegradable plastics from cheese whey can be produced by adding water slowly to the whey protein until adequate moisture. This procedure should be performed under constant stirring. Proteins and additives (such as plasticisers) are added in a hot press for 5 minutes under certain conditions $\left(150^{\circ} \mathrm{C}\right.$ and $20 \mathrm{MPa})$. Then samples are subjected to lower temperatures $\left(\leq 70^{\circ} \mathrm{C}\right)$, followed by cooling at room temperature. To characterize the resulting bioplastics, moisture content, thermal analysis (differential scanning calorimetry), spectroscopic analysis, and morphological and mechanical properties are determined (Sharma \& Luzinov, 2012). Future strategies for the manufacture of new bioplastics may use cheese whey as barrier containing Aspergillus oryzae spores. Aspergillus oryzae biomass in the barrier formulation will enable the consumption of the carbon source from whey - the lactose - with consequent degradation of the plastic.

\subsection{Hydrogen gas and biogas}


Hydrogen is a clean energy source, with no harmful by-products after combustion. On the world stage, hydrogen is seen as a potential successor of fossil fuels. In general, four strategies are available for obtaining hydrogen gas: water electrolysis, thermochemical processes, radiolytic processes, and fermentation process. Water electrolysis, thermochemical processes, and radiolytic processes present an unfavorable energy balance, i.e., the energy obtained is less than the energy expended. Therefore, the fermentation pathway has been highlighted in the scientific scenario for the production of biohydrogen, aiming at sustainable hydrogen production (Sarma et al., 2012; Sarma, Brar, Bihan, Buelna, \& Soccol, 2013). Biohydrogen has been produced by fermentation pathways, mainly from crude glycerol (a residue from biodiesel production). However, this technique is limited by the cost of the buffer and other nutrients required for the process (Sarma et al., 2013). Cheese whey has contributed greatly for providing nutrients for hydrogen-producing bacteria. Furthermore, in non-sterile conditions, high concentrations of whey may provide adverse conditions for non hydrogen-producing contaminants (Fernandez et al., 2014).

Cheese whey has also contributed to biogas production (Powell et al., 2013; Shilton et al., 2013). Biogas is composed of a large portion of methane gas and has large industrial applications. Among the uses of biogas, the steam generation stands out, replacing fuel oil, firewood, charcoal, or coal in industrial boilers. The biogas produced in the biodigestors can also be used as primary power source to provide mechanical power in engines and turbines and, when coupled to electrical generators, 
are capable of generating electricity. In addition, the methane gas can be used as raw material for the synthesis of a number of organic compounds (Balat \& Balat, 2009).

The production of these gases from cheese whey can be divided into two stages (Figure 4): first, the acidogenic phase using anaerobic fermentation bacteria, in which complex organic compounds present in whey as lactose, proteins and lipids are converted to volatile acids, hydrogen, and carbon dioxide. In the second stage, the products from the first stage will be converted to carbon dioxide and methane by methanogenic strains. The fermentation hydrogen production occurs in the first stage, while the biogas is produced in the second stage. 


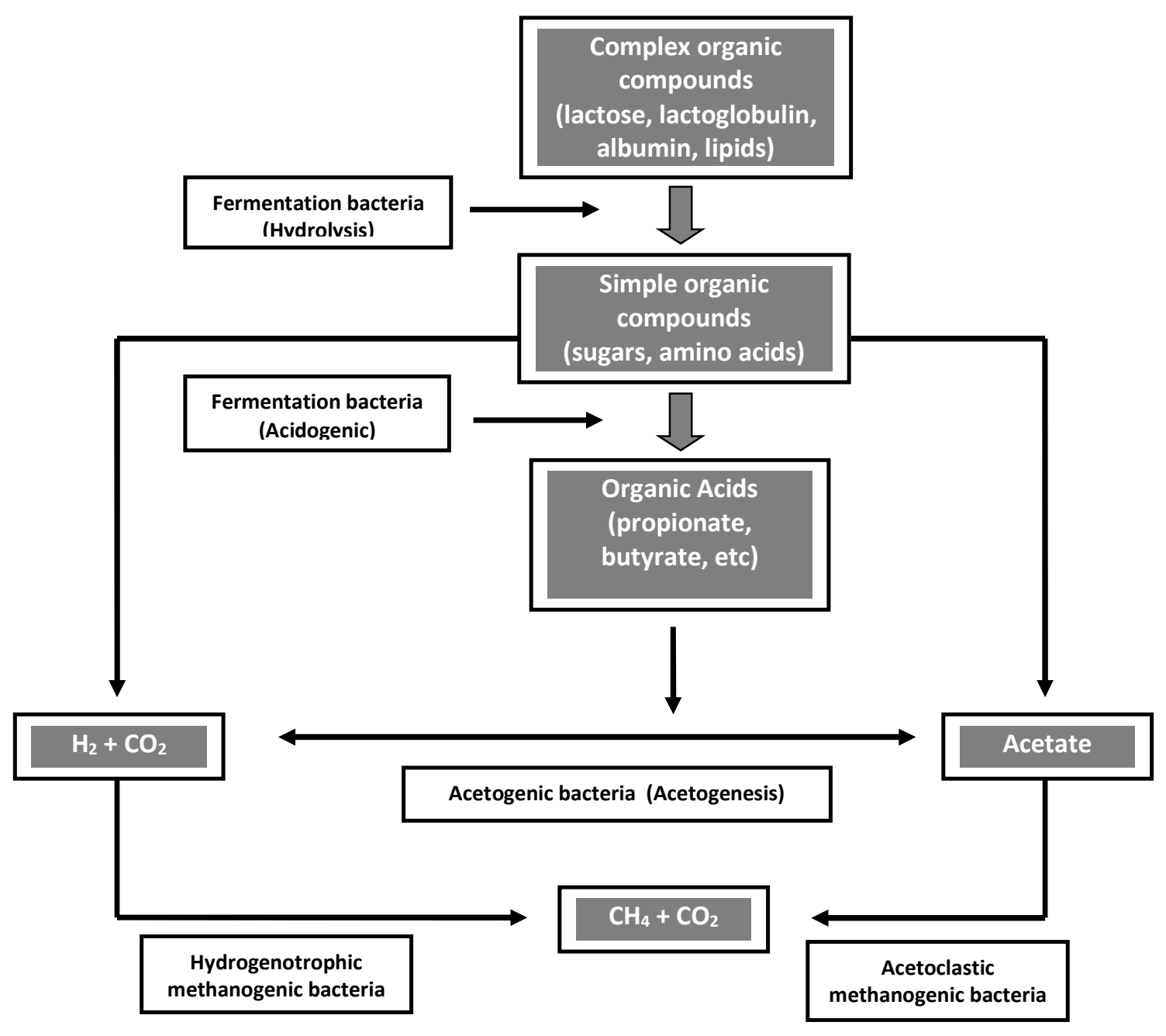

Figure 4-Simplified schematic representation of anaerobic digestion of complex substrates from whey. Adapted (Louzada, 2006).

\subsection{Organic Acids}

Organic acids have wide application in our daily lives. Food industries widely use organic acids as food additives. They can be used as alkalinity control agents, neutralizing agents or preservatives, due to its antimicrobial or antioxidant action (Yavuz \& Korukluoglu, 2013). Organic acids can be produced by probiotic strains during cheese manufacturing process. The production of organic acids by anaerobic 
fermentation is carried out by the acidogenic bacteria (Figure 4), thus a whey rich in organic acids is obtained from cheese manufacture (Madureira et al., 2013; Mullin \& Emmons, 1997). The quantification of these acids can be performed by titration with an alkali solution or by chromatographic methods such as the determination of orotic acid from cheese whey (Baumeister, Vogelmann, \& Fischer, 2003).

\subsection{Ethanol}

Ethanol has large industrial applications such as pharmaceuticals, perfumes, dyes, alcoholic beverages, fuel (mainly as an alternative to fossil fuels). Literature has shown that many lactose-fermenting strains are unable to ferment lactose in whey to produce ethanol. The vast majority of species of Saccharomyces are unable to metabolize lactose due to lack of enzymes such as lactate permease and $\beta$ galactosidase (Koushki et al., 2012). These enzymes are responsible respectively for the transport of lactose into the cytoplasm, and hydrolysis of lactose to glucose and galactose, by glycolytic pathway. Among the species widely used to ferment whey are Kluyveromyces and Candida kefyr (Koushki et al., 2012). Future appointments for production of ethanol from whey may focus on fermentation processes based on coculture systems. In this case, lactose-hydrolyzing strains, such as Aspergillus oryzae is used with consequent release of the monosaccharides glucose and galactose which can be assimilated by other traditional ethanolic fermentation strains such as Saccharomyces cerevisiae, or immobilization of beta-galactosidase in Saccharomyces cerevisiae for fermentation of cheese whey (Kisielewska, 2012). Other strategies also use methods of whey microfiltration, aiming at ethanol production. Microfiltration can be used to obtain a lactose-rich whey, allowing obtaining higher ethanol yields by 
fermentation process (Koushki et al., 2012). The use of bioreactor with immobilized cells (IC) has greatly contributed to the production of ethanol from whey as compared to traditional bioreactors with free cells. Such bioreactors IC have important functions such as cellular protection against aggressors and low reaction time which favors greater productivity (Gabardo, Rech, \& Zachia Ayub, 2012). Ultrasonication systems applied to ethanol fermentation process of cheese whey have also proven effective for promoting greater homogenization and dispersion of solutes in the fermentation medium, as well as increased activation / enzyme stabilization (Kisielewska, 2012).

\section{PERSPECTIVES}

The reduction of the environmental impact of waste from dairy industry, especially cheese whey, is certainly a challenge for the dairy productive chain, due to the high volume of whey produced per kilogram of cheese, and high chemical oxygen demand. Fortunately, studies have successfully produced value-added products through the fermentation of cheese whey or its physicochemical treatment. Among these products are organic acids, ribonucleotides, biodegradable plastics, bio-gas, hydrogen gas, and ethanol - these latter having good yields and competitive processes. However, there is a great research potential for new products, and possible optimization of the existing processes. Certainly, the use of fermentation processes in cheese whey will not replace the existing fermentation processes, for example the production of ethanol from sugar cane (traditional Brazilian perspective), but may play an important complementary role. Moreover, these fermentative and physicochemical treatments can contribute to the biorefinery concept which aims to integrate conversion processes and equipment to produce value-added products from a known 
bioprocess. In other words, we could obtain, besides the cheese, multiple other products.

\section{CONFLICT OF INTEREST}

The authors report no conflict of interest.

\section{REFERENCES}

Baieli, M. F., Urtasun, N., Miranda, M. V, Cascone, O., \& Wolman, F. J. (2014). Bovine lactoferrin purification from whey using Yellow HE-4R as the chromatographic affinity ligand. Journal of Separation Science, 37(5), 484-487.

Balat, M., \& Balat, H. (2009). Biogas as a renewable energy source - A Review. Energy Sources Part A-Recovery Utilization and Environmental Effects, 31(14), 12801293.

Balcao, V. M., Costa, C. I., Matos, C. M., Moutinho, C. G., Amorim, M., Pintado, M. E., Gomes, A. P., Vila, M. M., \& Teixeira, J. A. (2013). Nanoencapsulation of bovine lactoferrin for food and biopharmaceutical applications. Food Hydrocolloids, $32(2), 425-431$.

Baumeister, A., Vogelmann, S., \& Fischer, L. (2003). Concentration and purification of orotic acid directly from whey with an expanded bed adsorption system. Journal of Chromatography A, 1006(1-2), 261-265. 
Carrio, J. R., Fernandez, A., Riera, F. A., \& Suarez, A. (2014). Immunomodulatory activities of whey beta-lactoglobulin tryptic-digested fractions. International Dairy Journal, 34(1), 65-73.

Carvalho, B. M. A., Carvalho, L. M., Silva Jr., W. F., Minim, L. A., Soares, A. M., Carvalho, G. G. P., \& Da Silva, S. L. (2014). Direct capture of lactoferrin from cheese whey on supermacroporous column of polyacrylamide cryogel with copper ions. Food Chemistry, 154, 308-314.

Cheison, S. C., Bor, E. K., Faraj, A. K., \& Kulozik, U. (2012). Selective hydrolysis of alphalactalbumin by acid protease $A$ offers potential for beta-lactoglobulin purification in whey proteins. Food Science and Technology, 49(1), 117-122.

Daniel, D. E. L., Huerta, B. E. B., Mendoza, M. G. V, \& Sosa, I. A. (2013). Effect of drying conditions on the retention of phenolic compounds, anthocyanins and antioxidant activity of roselle (Hibiscus sabdariffa L.) added to yogurt. International Journal of Food Science and Technology, 48(11), 2283-2291.

Dos Santos, L. F., Melo, F. C. B. C., Paiva, W. J. M., Borsato, D., Silva, M. L. C. C., \& Celligoi, M. A. P. C. (2013). Characterization and optimization of levan production by Bacillus subtilis NATO. Romanian Biotechnological Letters, 18(4), 8413-8422.

Douphrate, D. I., Hagevoort, G. R., Nonnenmann, M. W., Kolstrup, C. L., Reynolds, S. J., Jakob, M., \& Kinsel, M. (2013). The dairy industry: A brief description of production practices, trends, and farm characteristics around the world. Journal of Agromedicine, 18(3), 187-197. 
Du, Q. Y., Lin, D. Q., Zhang, Q. L., \& Yao, S. J. (2014). An integrated expanded bed adsorption process for lactoferrin and immunoglobulin $\mathrm{G}$ purification from crude sweet whey. Journal of Chromatography B, 947, 201-207.

Fernandez, C., Carracedo, B., Martinez, E. J., Gomez, X., \& Moran, A. (2014). Application of a packed bed reactor for the production of hydrogen from cheese whey permeate: Effect of organic loading rate. Journal of Environmental Science and Health, 49(2), 210-217.

Fitzpatrick, J. J., Murphy, C., Mota, F. M., \& Pauli, T. (2003). Impurity and cost considerations for nutrient supplementation of whey permeate fermentations to produce lactic acid for biodegradable plastics. International Dairy Journal, 13(7), $575-580$.

Fornal, J. R., Jackson, C. G. R., Anderson, T. R., \& Greer, F. A. (2012). Effects of chocolate milk and a whey protein drink on muscle damage and performance. Medicine and Science in Sports and Exercise, 44(2), 451.

Gabardo, S., Rech, R., \& Zachia Ayub, M. A. (2012). Performance of different immobilized-cell systems to efficiently produce ethanol from whey: fluidized batch, packed-bed and fluidized continuous bioreactors. Journal of Chemical Technology and Biotechnology, 87(8), 1194-1201.

Holker, U., \& Lenz, J. (2005). Solid-state fermentation - are there any biotechnological advantages? Current Opinion in Microbiology, 8(3), 301-306. 
Hungaro, H. M., Calil, N. O., Ferreira, A. S., Chandel, A. K., \& Da Silva, S. S. (2013). Fermentative production of ribonucleotides from whey by Kluyveromyces marxianus: Effect of temperature and $\mathrm{pH}$. Journal of Food Science and Technology, 50(5), 958-964.

Jeon, J. R., \& Choi, J. H. (2010). Lactic acid fermentation of germinated barley fiber and proliferative function of colonic epithelial cells in loperamide-induced rats. Journal of Medicinal Food, 13(4), 950-960.

Jones, E. A. (1973). Some aspects of molecular-structure and functions of human immunoglobulin-G. Quarterly Journal of Medicine, 42(168), 835-836.

Karchemsky, F., Drug, E., Mashiach-Farkash, E., Fadeev, L., Wolfson, H. J., Gozin, M., \& Regev, O. (2013). Diameter-selective dispersion of carbon nanotubes by betalactoglobulin whey protein. Colloids and Surfaces B-Biointerfaces, 112, 16-22.

Kisielewska, M. (2012). Ultrasonic stimulation of co-immobilized Saccharomyces cerevisiae cells and beta-galactosidase enzyme for enhanced ethanol production from whey ultrafiltration permeate. Polish Journal of Environmental Studies, 21(2), 387-393.

Koushki, M., Jafari, M., \& Azizi, M. (2012). Comparison of ethanol production from cheese whey permeate by two yeast strains. Journal of Food Science and Technology, 49(5), 614-619. 
Krzeminska, D., Neczaj, E., \& Parkitna, K. (2013). Application of fenton reaction for supporting biological wastewater treatment from the dairy industry. Rocznik Ochrona Srodowiska, 15(3), 2381-2397.

Li, P., Xiu, G., Mata, V. G., Grande, C. A., \& Rodrigues, A. E. (2006). Expanded bed adsorption/desorption of proteins with streamline direct CST I adsorbent. Biotechnology and Bioengineering, 94(6), 1155-1163.

Lisak, K., Sierra, J. Y., Kulozik, U., Bozanic, R., \& Cheison, S. C. (2013). Chymotrypsin selectively digests beta-lactoglobulin in whey protein isolate away from enzyme optimal conditions: Potential for native alpha-lactalbumin purification. Journal of Dairy Research, 80(1), 14-20.

Louzada, A. G. (2006). Avaliação da atividade metanogênica específica de lodos com condicionamento hidrolítico provenientes do sistema UASB + BFS. Master's dissertation, Federal University of Espírito Santos, Goiabeiras/ES, Brazil.

Machado, I., Teixeira, J. A., \& Couto, S. R. (2013). Semi-solid-state fermentation: A promising alternative for neomycin production by the actinomycete Streptomyces fradiae. Journal of Biotechnology, 165(3-4), 195-200.

Madureira, A. R., Soares, J. C., Amorim, M., Tavares, T., Gomes, A. M., Pintado, M. M., \& Malcata, F. X. (2013). Bioactivity of probiotic whey cheese: Characterization of the content of peptides and organic acids. Journal of the Science of Food and Agriculture, 93(6), 1458-1465. 
Magalhaes, K. B., Rodrigues, W., \& Da Silveira, M. A. (2012). Social cost-benefit analysis chain production of ethanol of sweet potato in Tocantins State. Custos $e$ Agronegócio, 8(1), 143-160.

Malinovska, R. J., Fernandes, P., Winkelhausen, E., \& Fonseca, L. (2012). Galactooligosaccharides synthesis from lactose and whey by beta-galactosidase immobilized in PVA. Applied Biochemistry and Biotechnology, 168(5), 1197-1211.

Micinski, J., Zwierzchowski, G., Kowalski, I. M., \& Szarek, J. (2013). Health-promoting properties of selected milk components. Journal of Elementology, 18(1), 165-186.

Mullin, W. J., \& Emmons, D. B. (1997). Determination of organic acids and sugars in cheese, milk and whey by high performance liquid chromatography. Food Research International, 30(2), 147-151.

Musoles, R. R., Ruiz, M. C., Arce, C., Manzanares, P., Dolores Ivorra, M., \& Salom, J. B. (2014). Antihypertensive mechanism of lactoferrin-derived peptides: Angiotensin receptor blocking effect. Journal of Agricultural and Food Chemistry, 62(1), 173181.

Oguejiofor, W., Marshall, L. J., Price, R., \& Shur, J. (2013). Spray drying lactoferrin produces inhalable antimicrobial particles. Journal of Aerosol Medicine and Pulmonary Drug Delivery, 26(4), A259-A259.

Pazo, N. R., Araujo, L. V, Rodriguez, N. P., Dieguez, S. C., \& Dominguez, J. M. (2013). Cell-free supernatants obtained from fermentation of cheese whey hydrolyzates and phenylpyruvic acid by Lactobacillus plantarum as a source of antimicrobial 
compounds, bacteriocins, and natural aromas. Applied Biochemistry and Biotechnology, 171(4), 1042-1060.

Powell, N., Broughton, A., Pratt, C., \& Shilton, A. (2013). Effect of whey storage on biogas produced by co-digestion of sewage sludge and whey. Environmental Technology, 34(19), 2743-2748.

Queiroz, V. A., Assis, A. M., \& Júnior, H. C. R. (2013). Protective effect of human lactoferrin in the gastrointestinal tract. Revista Paulista de Pediatria, 31(1), 90-95.

Rademaker, J. L. W., Hoolwerf, J. D., Wagendorp, A. A., \& Giffel, M. C. (2006). Assessment of microbial population dynamics during yoghurt and hard cheese fermentation and ripening by DNA population fingerprinting. International Dairy Journal, 16(5), 457-466.

Roveda, M., Hemkemeier, M., \& Colla, L. M. (2010). Evaluation of lipase production using different strains of microorganisms isolated from dairy effluent through submerged fermentation. Ciencia e Tecnologia de Alimentos, 30(1), 126-131.

Samuelov, N. S., Datta, R., Jain, M. K., \& Zeikus, J. G. (1999). Whey fermentation by Anaerobiospirillum succiniciproducens for production of a succinate-based animal feed additive. Applied and Environmental Microbiology, 65(5), 2260-2263.

Sarma, S. J., Brar, S. K., Bihan, Y. L., Buelna, G., \& Soccol, C. R. (2013). Hydrogen production from meat processing and restaurant waste derived crude glycerol by anaerobic fermentation and utilization of the spent broth. Journal of Chemical Technology and Biotechnology, 88(12), 2264-2271. 
Sarma, S. J., Brar, S. K., Sydney, E. B., Bihan, Y. Le, Buelna, G., \& Soccol, C. R. (2012). Microbial hydrogen production by bioconversion of crude glycerol: A review. International Journal of Hydrogen Energy, 37(8), 6473-6490.

Schaller, J. P., Buck, R. H., \& Rueda, R. (2007). Ribonucleotides: Conditionally essential nutrients shown to enhance immune function and reduce diarrheal disease in infants. Seminars in Fetal and Neonatal Medicine, 12(1), 35-44.

Sekiyu, S. S. (1992). Citric acid prepn. by aerobic fermentation - using Candida yeast strain and carbon source, and blowing oxygen into culture medium. Patent JP61219391-A (JP92076676-B) Showa Shell Sekiyu KK, Tokyo, Japan.

Sharafedtinov, K. K., Plotnikova, O. A., Alexeeva, R. I., Sentsova, T. B., Songisepp, E., Stsepetova, J., Smidt, I., \& Mikelsaar, M. (2013). Hypocaloric diet supplemented with probiotic cheese improves body mass index and blood pressure indices of obese hypertensive patients - a randomized double-blind placebo-controlled pilot study. Nutrition Journal, 12, 138-138.

Sharma, S., Hodges, J. N., \& Luzinov, I. (2008). Biodegradable plastics from animal protein coproducts: Feathermeal. Journal of Applied Polymer Science, 110(1), 459-467.

Sharma, S., \& Luzinov, I. (2012). Water aided fabrication of whey and albumin plastics. Journal of Polymers and the Environment, 20(3), 681-689. 
Shilton, A., Powell, N., Broughton, A., Pratt, C., Pratt, S., \& Pepper, C. (2013). Enhanced biogas production using cow manure to stabilize co-digestion of whey and primary sludge. Environmental Technology, 34(17), 2491-2496.

Sierra, J. T., Tolkach, A., \& Kulozik, U. (2013). Fractionation of alpha-lactalbumin and beta-lactoglobulin from whey protein isolate using selective thermal aggregation, an optimized membrane separation procedure and resolubilization techniques at pilot plant scale. Food and Bioprocess Technology, 6(4), 1032-1043.

Silva, M. R., Silvestre, M. P. C., Silva, V. D. M., Souza, M. W. S., Lopes Junior, C. O., Afonso, W. O., Lana, F. C., \& Rodrigues, D. F. (2014). Production of ace-inhibitory whey protein concentrate hydrolysates: use of pancreatin and papain. International Journal of Food Properties, 17(5), 1002-1012.

Silveira, S. T., Martinez-Maqueda, D., Recio, I., \& Ledesma, B. H. (2013). Dipeptidyl peptidase-IV inhibitory peptides generated by tryptic hydrolysis of a whey protein concentrate rich in beta-lactoglobulin. Food Chemistry, 141(2), 1072-1077.

Siqueira, A. M. O., Machado, E. C. L., \& Stamford, T. L. M. (2013). Dairy beverage containing cheese whey and fruit. Ciência Rural, 43(9), 1693-1700.

Sommer, N., Ghofrani, H. A., \& Schermuly, R. T. (2008). Oxygen dependency of mitochondrial respiratory chain function in hypoxic pulmonary vasoconstriction. Biochimica et Biophysica Acta-Bioenergetics, 1777, S53.

Thinnes, B. (2013). Biodegradable plastics demand should grow $15 \%$ annually from 2012 to 2017. Hydrocarbon Processing, 92(6), np. 
Vekovischeva, O. Y., Peuhkuri, K., Backstrom, P., Sihvola, N., Pilvi, T., \& Korpela, R. (2013). The effects of native whey and alpha-lactalbumin on the social and individual behaviour of C57BL/6J mice. British Journal of Nutrition, 110(7), 13361346.

Ventanas, S., Mustonen, S., Puolanne, E., \& Tuorila, H. (2010). Odour and flavour perception in flavoured model systems: Influence of sodium chloride, umami compounds and serving temperature. Food Quality and Preference, 21(5), 453462.

Wissmann, M. A., Hein, A. F., Follmann, J., \& Rachow, N. I. P. (2012). Environmental costs: analysis of its impact and importance in the pursuit of eco-efficiency in an industry of cheese. Custos e Agronegócio, 8(3), 2-23.

Yavuz, M., \& Korukluoglu, M. (2013). The efficacy of potassium sorbate and organic acids in the control of food spoilage yeasts. Journal of Animal and Veterinary Advances, 12(1), 62-68.

Yin, C. M., Wong, J. H., Xia, J., \& Ng, T. B. (2013). Studies on Anticancer Activities of Lactoferrin and Lactoferricin. Current Protein and Peptide Science, 14(6), 492-503.

Zhang, S., Hsieh, F. H., \& Vardhanabhuti, B. (2014). Acid-induced gelation properties of heated whey protein-pectin soluble complex (Part I): Effect of initial pH. Food Hydrocolloids, 36, 76-84. 